\title{
Herbicidal Properties of Sethoxydim for the Control of Gramineous Weeds
}

\author{
Hisao Ishikawa, Shozo Yamada, Hideo Hosaka, Takashi Kawana, * \\ Susumu Okunuki and Kenichi KoHARA \\ Nisso Institute for Life Science, Nippon Soda Co., Ltd., Oiso-cho, \\ Naka-gun, Kanagawa 255, Japan
}

(Received August 14, 1984)

\begin{abstract}
Herbicidal properties of a new post-emergence herbicide, sethoxydim $\{( \pm)$-2-(1-ethoxyiminobutyl)-5-[2-(ethylthio)propyl]-3-hydroxycyclohex-2-enone\} were evaluated mainly in a greenhouse. Sethoxydim showed excellent activity against gramineous plants other than annual bluegrass (Poa annua) and significant selectivity between grassy weeds and bloadleaved crops. Most annual grasses and perennial grasses were perfectly controlled at $0.2-0.4$ $\mathrm{kg} / \mathrm{ha}$ and at $0.5-1.0 \mathrm{~kg} / \mathrm{ha}$, respectively, whereas bloadleaved crops showed extremely high tolerance to sethoxydim. Sethoxydim was 7-8 times more active against johnsongrass (Sorghum halepence) than alloxydim-sodium. It appeared that sethoxydim was rapidly absorbed and readily basipetally translocated. Sethoxydim showed higher activity in postemergence treatment than in pre-emergence treatment. It was presumed that the cause of low activity of sethoxydim in pre-emergence treatment was attributable to its short persistence and high movement in soil.
\end{abstract}

\section{INTRODUCTION}

Sethoxydim $\{( \pm)-2-(1-$ ethoxyiminobutyl)-5[2- (ethylthio) propyl] - 3 - hydroxycyclohex - 2enone $\}$ was discovered as an analogue of alloxydim-sodium [methyl 3-(1-allyloxyaminobutylidene) -6,6-dimethyl-2,4-dioxocyclohexylcarboxylate] which has already been commercialized and used broadly as a grasskiller in broadleaved crops. However it failed to give sufficient control of perennial grass weeds, especially johnsongrass (Sorghum halepense). Thus a new product having more potent activity for the control of this weed was required. As a result of further investigation, sethoxydim was found as a new product.

The present investigation was undertaken to make clear its herbicidal properties by comparing with those of alloxydim-sodium. This study was conducted mainly in a greenhouse.

* Present address: Agro-Pharm Division, Nippon Soda Co., Ltd., Chiyoda-ku, Tokyo 100, Japan.

\section{MATERIALS AND METHODS}

\section{Chemicals}

Sethoxydim and alloxydim-sodium were synthesized in Fine Chemicals Research Laboratory of Nippon Soda Co., Ltd. They were more than $98 \%$ pure. Sethoxydim was dissolved in $0.2 \mathrm{ml}$ of aceton containing $10 \%$ Tween-20 and $0.4 \mathrm{ml}$ of dimethylformamide, and alloxydim-sodium was directly dissolved in water containing $500 \mathrm{ppm}$ of Tween-20. Then they were diluted with water to give various concentrations. Final concentration of surfactant was made equal in all solutions.

In field experiments, $20 \%$ emulsifiable concentration of sethoxydim and $75 \%$ wettable powder of alloxydim-sodium were used.

\section{Pre- and Post-emergence Treatment}

Pots having a surface area of $100 \mathrm{~cm}^{2}$ were filled with light clay soil $(\mathrm{pH} 5.7)$. Various plant seeds were sown properly and covered with 1 to $2 \mathrm{~mm}$ of soil and then pots were kept 
in a greenhouse $\left(18-25^{\circ} \mathrm{C}\right)$. In pre-treatment, aqueous solutions of sethoxydim were immediately sprayed on the soil surface at a rate of $1000 \mathrm{l} / \mathrm{ha}$ with a microsprayer. In posttreatment, sethoxydim was applied on the foliage of the plants at various stages by the same method. Crops were treated after thinning to 4 to 6 plants per pot to uniform stages of growth.

Eight to fifteen $\mathrm{cm}$ rhizome fragments of perennial grasses were planted $1-2 \mathrm{~cm}$ deep in pots of $15 \mathrm{~cm}$ in diameter and grown in a greenhouse.

Visual assessment was conducted three weeks after treatment for annual grasses and four weeks after treatment for perennial grasses on a scale of values of 0 (no effect)-10 (dead).

\section{Soil Persistence Test}

Soil was put into clay pots having $12 \mathrm{~cm}$ diameter and aqueous solutions of sethoxydim were applied on the soil surface at a rate of 1 $\mathrm{kg} / \mathrm{ha}$ using a microsprayer and the pots were kept in a greenhouse. One group of treated pots was watered over the pots two or three times daily to maintain moderate soil moisture and the other was kept dry. Each week after application thirty seeds of barnyardgrass (Echinochloa crus-galli) which had already been germinated were sown in the pots and were watered. After placing the pots in the shade for two days, they were kept under natural daylight. After two weeks fresh weights of plants were measured.

\section{Soil Leaching Test}

Soil was packed in a column which was constructed from ten separable parts. One part was $9 \mathrm{~cm}$ in diameter and $1 \mathrm{~cm}$ in height. The column was kept in vertical position. The herbicides were applied on the soil surface in the column at a rate of $1 \mathrm{~kg} / \mathrm{ha}$ with water volume of $1000 \mathrm{l} / \mathrm{ha}$. One day after application an artifitial rainfall of $15 \mathrm{~mm}$ for four hours was given to the column.

After standing for two days, the column was taken away one by one from the top part. Each clod of soil from ten parts was placed in petri dishes separately and thirty seeds of barnyardgrass were planted and incubated in a controlled chamber $\left(25^{\circ} \mathrm{C}\right.$ dark $)$. After five days their shoot lengths were measured.

\section{Field Trial}

The experiment was carried out at Haibara Agricultural Research Station of Nippon Soda Co., Ltd. in Shizuoka prefecture. A field infested with johnsongrass growing from rhizome at 5-6 leaf stage was plotted. One plot was $2 \times 1.5 \mathrm{~m}$ in size. The aqueous solutions prepared by diluting an emulsifiable concentrate with water were applied on foliage of the plants at a rate of $1000 \mathrm{l} / \mathrm{ha}$ by using a handheld boom sprayer.

The application and the evaluation were conducted on May 23 and October 27 in 1982, respectively. The visual assessment was done with the same scale as described above and fresh weights of rhizome per $0.25 \mathrm{~m}^{2}$ were measured in some plots.

\section{Absorption and Simulated Rainfall Test}

Each aqueous solution was applied on foliage of barnyardgrass growing in $100 \mathrm{~cm}^{2}$ pots at a rate of $500 l /$ ha. Leaf stage was 2 week old plants before earing, and plant height was 30 $50 \mathrm{~cm}$. Prior to application, the soil surface of pots and the stems were covered with vermiculite and alminium foil respectively to prevent the herbicides adhering to them. After treatment they were removed. Then the pots were kept in a greenhouse. At various periods of time after application the plant shoots in each pots were cut off at $5 \mathrm{~cm}$ level from the soil surface. The lengths of new leaves developing from the residual stem were measured.

In rainfall experiment, yellow foxtail (Setaria viridis) at 5 leaf stage growing in $100 \mathrm{~cm}^{2}$ pots were sprayed with $0.05,0.1$ and $0.2 \mathrm{~kg} / \mathrm{ha}$ of sethoxydim by a microsprayer with $1000 \mathrm{l} / \mathrm{ha}$ of spray volume. The pots were placed in a greenhouse. At 1, 3 and $6 \mathrm{hr}$ after treatment, a $10 \mathrm{~mm}$ simulated rainfall was applied for 3 hr by using artifitial rainfall apparatus (Taikirika Kogyo Co., Ltd.) and pots were replaced in a greenhouse. Three weeks later fresh weights of the shoots were measured.

\section{RESULTS}

\section{Herbicidal Activity and Selectivity}

Herbicidal activities of sethoxydim against 
Table 1 Herbicidal activities of sethoxydim in foliar application on annual weeds species 3 weeks after treatment.

\begin{tabular}{|c|c|c|c|c|c|c|c|}
\hline \multirow{2}{*}{ Species } & \multirow{2}{*}{$\begin{array}{c}\text { Leaf } \\
\text { stage }\end{array}$} & \multicolumn{6}{|c|}{ Rate (kg/ha) } \\
\hline & & 0.05 & 0.1 & 0.2 & 0.4 & 2 & 4 \\
\hline Digitaria adscendens & $\left.4 L-t^{a}\right)$ & 5 & 9 & 10 & 10 & 10 & 10 \\
\hline Setaria viridis & 4L-7L & 3 & 7 & 9 & 10 & 10 & 10 \\
\hline Setaria faberi & 4L-7L & 2 & 6 & 9 & 10 & 10 & 10 \\
\hline Echinochloa crus-galli & $4 L-t$ & 3 & 7 & 9 & 10 & 10 & 10 \\
\hline Alopecurus aequalis & $4 \mathrm{~L}-\mathrm{t}$ & 7 & 9 & 10 & 10 & 10 & 10 \\
\hline Avena fatua & $4 \mathrm{~L}-6 \mathrm{~L}$ & 3 & 8 & 10 & 10 & 10 & 10 \\
\hline Poa annua & $3 \mathrm{~L}-5 \mathrm{~L}$ & 0 & 0 & 0 & 0 & 7 & 10 \\
\hline Cyperus microiria & $2 \mathrm{~L}-3 \mathrm{~L}$ & 0 & 0 & 0 & 0 & 0 & 1 \\
\hline Chenopodium album & $2 \mathrm{~L}-4 \mathrm{~L}$ & 0 & 0 & 0 & 0 & 2 & 4 \\
\hline Amaranthus lividus & $2 \mathrm{~L}-3 \mathrm{~L}$ & 0 & 0 & 0 & 0 & 1 & 2 \\
\hline Stellaria media & $3 \mathrm{~L}-7 \mathrm{~L}$ & 0 & 0 & 0 & 0 & 2 & 2 \\
\hline Polygonum blumei & $2 \mathrm{~L}-4 \mathrm{~L}$ & 0 & 0 & 0 & 0 & 1 & 2 \\
\hline Xanthium strumarium & $2 \mathrm{~L}-3 \mathrm{~L}$ & 0 & 0 & 0 & 0 & 0 & 1 \\
\hline
\end{tabular}

a) $\mathrm{t}$ : tillering.

typical annual grasses (shown in Table 1) showed high at 4 leaf stage or more at $0.1-0.2$ $\mathrm{kg} /$ ha. However it was not sufficient to control annual bluegrass at the same dose. A dosage of more than $2 \mathrm{~kg} / \mathrm{ha}$ was required to control this weed perfectly. On the other hand, it showed little activity on bloadleaved weeds even at $4 \mathrm{~kg} / \mathrm{ha}$.

Thus it can be said that there was a significant difference in sensitivity between gramineous weeds and bloadleaved weeds. The difference in sensitivity among various crops is indicated in Table 2. Sethoxydim caused significant activity in gramineous crops such as wheat and corn at $0.2 \mathrm{~kg} / \mathrm{ha}$ or more but non-gramineous crops revealed extremely good tolerance to sethoxydim at $2 \mathrm{~kg} / \mathrm{ha}$. Against perennial grasses a little more dose of sethoxydim was required for control compared with annual grasses but it showed effective control of perennial grasses at a rate of $0.5-1.0 \mathrm{~kg} / \mathrm{ha}$ (Table 3).

From these results it is clear that sethoxydim has high selective phytotoxicity between gramineous plants and bload-leaved ones. Further, though it is 3 to 4 times more active than alloxydim-sodium to annual grasses, ${ }^{1,2)}$ it showed 7 to 8 times more effective control on johnsongrass. A similar result was obtained in field test (Table 4), in which it reduced fresh
Table 2 Tolerance of several crops to sethoxydim in foliar application at 2-4 leaves stage.

\begin{tabular}{|c|c|c|c|c|}
\hline \multirow{2}{*}{ Crop } & \multicolumn{4}{|c|}{ Rate (kg/ha) } \\
\hline & 0.2 & 0.4 & 1.0 & 2.0 \\
\hline Soybean & 0 & 0 & 0 & 2 \\
\hline Tomato & 0 & 0 & 0 & 0 \\
\hline Lettuce & 0 & 0 & 0 & 0 \\
\hline Radish & 0 & 0 & 0 & 0 \\
\hline Sugar beet & 0 & 0 & 0 & 0 \\
\hline Cotton & 0 & 0 & 0 & 0 \\
\hline Onion & 0 & 0 & 0 & 0 \\
\hline Carrot & 0 & 0 & 0 & 0 \\
\hline Cucumber & 0 & 0 & 0 & 0 \\
\hline Cabbage & 0 & 0 & 0 & 0 \\
\hline Peanut & 0 & 0 & 0 & 3 \\
\hline Pea & 0 & 0 & 0 & 0 \\
\hline Wheat & 9 & 9 & 10 & 10 \\
\hline Barley & 9 & 10 & 10 & 10 \\
\hline Corn & 9 & 10 & 10 & 10 \\
\hline Rice & 9 & 10 & 10 & 10 \\
\hline
\end{tabular}

weight of rhizome by $30 \%$ compared to the untreated plot (Table 5).

\section{Foliar Absorption and Movement into the Symplast}

It has been considered that the site of action of alloxydim-sodium is in the meristematic 
Table 3 Herbicidal activities of sethoxydim and alloxydim-sodium in foliar application on some perennial grass weeds.

\begin{tabular}{|c|c|c|c|c|c|c|}
\hline \multirow{2}{*}{$\begin{array}{l}\text { Rate } \\
\mathrm{kg} / \mathrm{ha}\end{array}$} & \multicolumn{2}{|c|}{$\begin{array}{c}\text { Sorghum halepense } \\
3-6 \mathrm{~L}^{\mathrm{a})}\end{array}$} & \multicolumn{2}{|c|}{$\begin{array}{c}\text { Agropyron repense } \\
3-4 \mathrm{~L}^{\mathrm{a})}\end{array}$} & \multicolumn{2}{|c|}{$\begin{array}{l}\text { Cynodon dactylon } \\
8-15 \mathrm{~cm}^{\mathrm{b})}\end{array}$} \\
\hline & Sethoxydim & $\begin{array}{l}\text { Alloxydim- } \\
\text { sodium }\end{array}$ & Sethoxydim & $\begin{array}{l}\text { Alloxydim- } \\
\text { sodium }\end{array}$ & Sethoxydim & $\begin{array}{l}\text { Alloxydim- } \\
\text { sodium }\end{array}$ \\
\hline 0.13 & 2 & 0 & 0 & 0 & 2 & - \\
\hline 0.25 & 7 & 0 & 2 & 0 & 6 & - \\
\hline 0.50 & 10 & 1 & 8 & 1 & 9 & - \\
\hline 1.00 & 10 & 2 & 10 & 8 & 10 & - \\
\hline 2.00 & 10 & 4 & 10 & 10 & 10 & - \\
\hline 4.00 & 10 & 9 & 10 & 10 & 10 & - \\
\hline
\end{tabular}

a) Leaf stage, b) Stolon length, —: Not applied.

Table 4 Herbicidal activity of sethoxydim on johnsongrass in field foliar application.

\begin{tabular}{lccl}
\hline \multirow{2}{*}{ Herbicide } & $\mathrm{kg} / \mathrm{ha}$ & \multicolumn{2}{c}{ Leaf stage } \\
\cline { 3 - 4 } & & $2-4.5$ & $7-8$ \\
\hline \multirow{3}{*}{ Sethoxydim } & 0.50 & 8 & 7 \\
& 0.75 & 9.5 & 7.5 \\
& 1.00 & 10 & 8 \\
\hline \multirow{3}{*}{ Alloxydim-sodium } & 1.00 & 2 & 1 \\
& 1.50 & 3 & 1 \\
& 2.00 & 6 & 3 \\
\hline
\end{tabular}

region like the apical meristem of the plant, ${ }^{3)}$ so sethoxydim having very similar chemical structure and herbicidal symptom also conceivably attacks the same site. Therefore the difference in foliar uptake and movement within the leaf of both compounds was compared. Sethoxydim at $0.5 \mathrm{~kg} / \mathrm{ha}$ completely inhibited new leaf emergence from the end of cut stems when there were $6 \mathrm{hr}$ or more interval between leaf cut and the application time. On the other hand, alloxydim-sodium at $2 \mathrm{~kg} / \mathrm{ha}$ required
Table 5 Effect of sethoxydim on root growth of johnsongrass in field foliar application.

\begin{tabular}{lccc}
\hline \multicolumn{1}{c}{ Herbicide } & $\mathrm{kg} / \mathrm{ha}$ & $\begin{array}{c}\text { Rhizome } \\
\text { weight }(\mathrm{g})\end{array}$ & $\%$ of cont. \\
\hline Sethoxydim & 0.5 & 85 & 26.9 \\
Untreated & - & 280 & 100 \\
\hline
\end{tabular}

more than $12 \mathrm{hr}$ to obtain the same effect (Table 6). This suggests that sethoxydim is absorbed in the lethal concentration and basipetally moved more rapidly than alloxydim-sodium. In simulated rainfall test, rainfall later than $3 \mathrm{hr}$ after application did not reduce any activity on yellow foxtail (Fig. 1).

\section{Leaching and Persistence in Soil}

Sethoxydim was fairly less active in pretreatment than in post-treatment (Fig. 2). It was presumed that a significant leaching and short persistence of sethoxydim in soil were the main causal factors. Actually sethoxydim was relatively well leached by simulated rain-

Table 6 Regrowth of barnyardgrass after cutting of leaves treated with sethoxydim.

\begin{tabular}{|c|c|c|c|c|c|c|c|}
\hline \multirow[t]{2}{*}{ Herbicide $\mathrm{kg} / \mathrm{ha}$} & & \multicolumn{6}{|c|}{$\begin{array}{l}\text { Leaf elongation ( } \% \text { of cont.) } \\
\text { Hours after treatment when treated leaves were cut }\end{array}$} \\
\hline & & 1 & 3 & 6 & 12 & 24 & 48 \\
\hline \multirow[t]{2}{*}{ Sethoxydim } & 0.5 & 103.8 & 26.5 & 0 & 0 & 0 & 0 \\
\hline & 1.0 & 7.2 & 0 & 0 & 0 & 0 & 0 \\
\hline \multirow[t]{2}{*}{ Alloxydim-sodium } & 1.0 & 93.7 & 109.3 & 108.6 & 20.8 & 25.4 & 0 \\
\hline & 2.0 & 57.7 & 27.3 & 9.8 & 0 & 0 & 0 \\
\hline
\end{tabular}




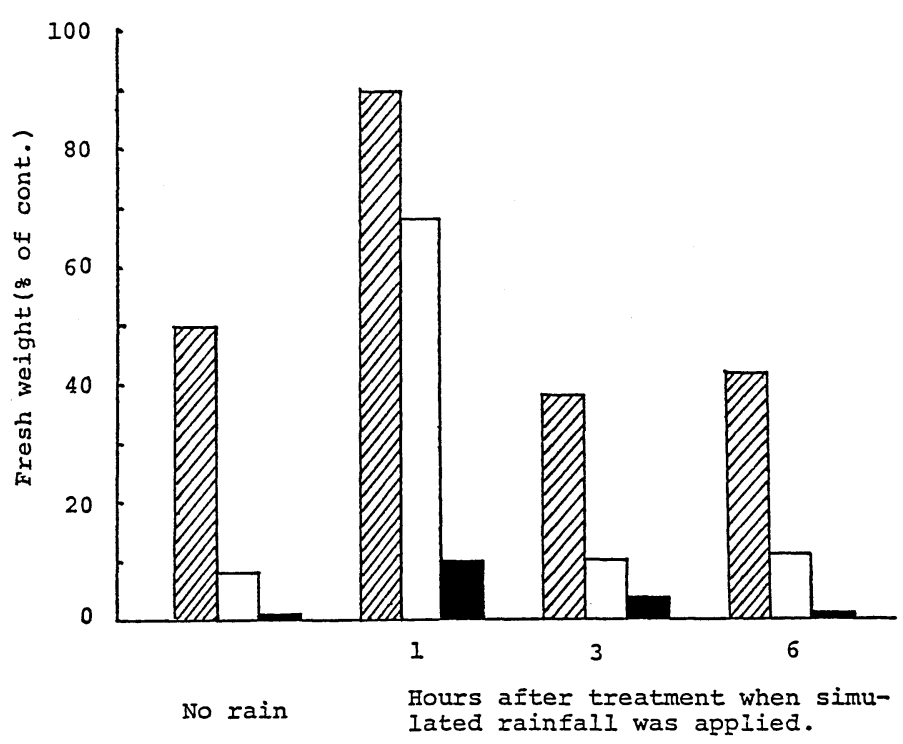

Fig. 1 Effects of simulated rainfall on the activity of sethoxydim on green foxtail. then: $0.05 \mathrm{~kg} / \mathrm{ha}$, $0.1 \mathrm{~kg} / \mathrm{ha}$, $0.2 \mathrm{~kg} / \mathrm{ha}$



Fig. 2 Herbicidal activities of sethoxydim in pre- and post-emergence treatment. vigitaria adscendens, Setaria viridis,

口: Avena fatua

fall in soil compared with other herbicides such as simazine and trifluralin (Fig. 3). The herbicidal activity in soil was lost within two weeks under dry conditions or four weeks under wet conditions (Fig. 4).

\section{DISCUSSION}

Though sethoxydim showed excellent herbicidal activity against annual and perennial grassy plants at a dose less than $1 \mathrm{~kg} / \mathrm{ha}$, it had little efficacy against bloadleaved plants even 


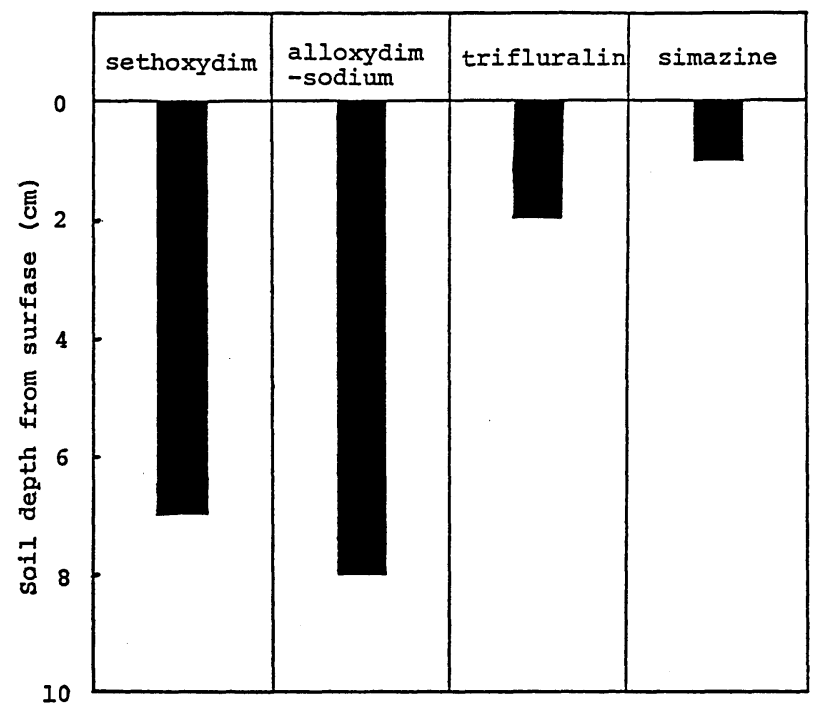

Fig. 3 Movement of sethoxydim and alloxydim-sodium causing a $50 \%$ or more reduction in barnyardgrass shoots length in soil.

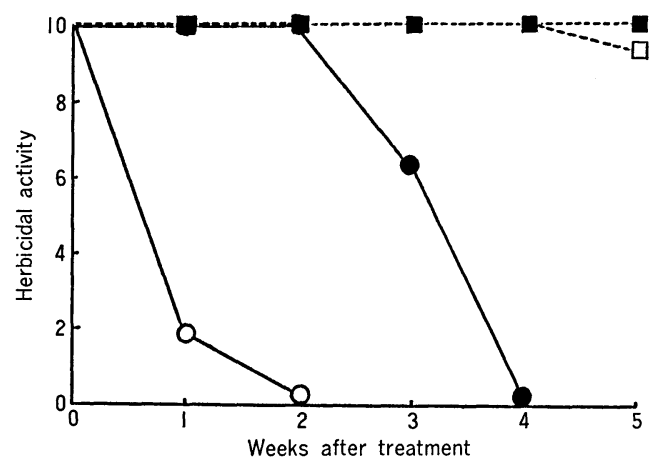

Fig. 4 Persistence of sethoxydim in soil.

$\mathrm{O}$ : sethoxydim $1 \mathrm{~kg} /$ ha dry condition,

๑: sethoxydim $1 \mathrm{~kg} /$ ha wet condition,

$\square$ : simazine $2 \mathrm{~kg} / \mathrm{ha}$ dry condition,

घ: simazine $2 \mathrm{~kg} / \mathrm{ha}$ wet condition.

at $4 \mathrm{~kg} / \mathrm{ha}$. Thus it is clear that sethoxydim shows a significant selectivity between gramineous plants and bloadleaved ones.

The results of the absorption and simulated rainfall tests suggested that the significant factor that sethoxydim is more active than alloxydim-sodium on johnsongrass as well as annual species depends on its greater uptake and movement in plants. Furthermore sethoxydim showed remarkably high activity against johnsongrass compared to alloxydim-sodium. Johnsongrass was especially susceptible to sethoxydim. Sethoxydim provided insufficient control on annual bluegrass as did alloxydimsodium. In the case of alloxydim-sodium, this was conceivably attributed to the low uptake by the plant.") However it is now not clear whether sethoxydim also works in the same way.

Sethoxydim was less effective in pre-treatment than in post-treatment. This is probably due to the high soil leaching and the short persistence in soil. Smith et al. ${ }^{5)}$ reported that ${ }^{14} \mathrm{C}$-sethoxydim was rapidly degraded in soil under laboratory and field conditions. From the present results, it is similarly suggested that sethoxydim is rapidly decomposed in soils.

From these data, it is indicated that sethoxydim should be used not as a pre-emergence herbicide but as a post-emergence herbicide, and sethoxydim applied on foliage is rapidly absorbed and readily moved basipetally from the treated foliage to the site of action within the plants, resulting in the herbicidal action.

\section{REFERENCES}

1) A. Formigoni, I. Lwataki \& H. Ishikawa: Abstr. IX Int. Congr. Plant Prot., No. 477, 1979 
2) G. H. Ingran \& A. T. Slater: Proc. Br. Crop Prot. Conf. Weeds, p. 39, 1980

3) H. Ishikawa, S. Okunuki, T. Kawana \& Y. Hirono: J. Pesticide Sci. 5, 523 (1980)

4) Y. Hirono \& H. Ishikawa: Chem. Regul. Plants 16, 137 (1981)

5) A. Smith \& A. Hsiao: Weed Res. 23, 253 (1983)

\section{要 約}

\section{イネ科雑草防除剂 sethoxydim の除草特性}

石川尚雄, 山田正三, 保坂秀夫, 川名 貴 奥貫 進, 小原健一

新規なイネ科雑草防除剤 sethoxydim $\{( \pm)-2$-(1ethoxyiminobutyl)-5-[2-(ethylthio) propyl]-3-hydroxy- cyclohex-2-enone\} の殺草特性をおもに温室内で検討し た. 一年生, 多年生イネ科植物には, $0.2 \sim 1.0 \mathrm{~kg} / \mathrm{ha} て ゙$ 高い効力を示したが, 広葉植物には, $4 \mathrm{~kg} / \mathrm{ha}$ でもほと んど活性がなく，イネ科植物と広葉植物間に大きな感受 性差が認められた. しかしながら，イネ科植物のなかで もスズメノカタビラには活性が劣った. Sethoxydim は，多年生のセイバンモロコシには alloxydim-sodium に比べて 7〜8 倍の高い効力を示した. Sethoxydim は alloxydim-sodium に比べ, 植物体内への取込みと, 体 内での移動が早いことが推察された. また, sethoxydim の土壤中での残効は短く, 下方移動が大きいことがわか った. このことが土壤処理で活性が低い一要因と考えら れる。 